\title{
Impact Assessment of Extension Program on Hybrid Rice Adoption in Myanmar
}

\author{
Phyu Lay MYINT ${ }^{1 *}$, Orachos Napasintuwong ${ }^{2}$, Naing KYI WIN ${ }^{3}$ \\ ${ }^{1}$ Staff Officer, Extension Division, Department of Agriculture (DOA), Ministry of Agriculture, Livestock and Irrigation \\ (MOALI), 15011 Nay Pyi Taw, Myanmar. Email: phyulaymyint1980@gmail.com. \\ ${ }^{2}$ Department of Agricultural and Resource Economics, Faculty of Economics, Kasetsart University, 10900 Bangkok, \\ Thailand, Email: orachos@gmail.com. \\ ${ }^{3}$ Director General, Department of Agricultural Research (DAR), Ministry of Agriculture, Livestock and Irrigation \\ (MOALI), Yezin, Myanmar. Email: naingkyiwinwin9@gmail.com.
}

How to cite this paper: MYINT PL., Napasintuwong O., KYI WIN N. (2019) Impact Assessment of Extension Program on Hybrid Rice Adoption in Myanmar. International Journal of Food Science and Agriculture, 3(3), 159-172.

DOI: $10.26855 /$ ijfsa.2019.09.003

*Corresponding author: Phyu Lay MYINT, Staff Officer, Extension Division, Department of Agriculture (DOA), Ministry of Agriculture, Livestock and Irrigation (MOALI), 15011 Nay Pyi Taw, Myanmar.

Email: phyulaymyint1980@gmail.com

\begin{abstract}
In Myanmar, almost all of research activities are centered on Extension Division that organized with versatile agricultural specialists who are most likely to distribute research activities and new innovation technologies to remote areas. Pearl Thwe hybrid rice seed production was introduced in 2011/2012 in monsoon, for poverty alleviation and better living standard of farmers due to its higher yield. Sown area however is very limited to adopt. The purposes of this study are to evaluate the impact assessment of extension program by benefit-cost ratio (B:C), and to examine the most effective methodologies by marginal effect. The seasonal data (580 sample sizes) were collected in 58 Townships of four State and Regions, from 2011/2012 to 2015/2016.

The results showed that annual average growth rate of Pearl Thwe adoption in Nay Pyi Taw, Kachin, Kayin, Chin, Tanintharyi, Bago and Magway Region/ State are satisfied while the rest State and Region are highly unsatisfactory. Nevertheless, Sagaing, Mandalay, Mon, Shan and Ayeyarwaddy Region/State increased adoption areas yearly even having decreasing growth rate. Among still operating various extension methods in Myanmar, field day, media and field-trial are the best, and demonstration and farmer-field-school are also satisfied whilst integrated method, workshop, other method (traditionally), training and group discussion methods are unsatisfactory for hybrid rice adoption, in accordance with cost (applied extension methodologies) and benefit (Pearl Thwe' adoption). By the perception and perception score of Township Officer, farmer field school, workshop, other method, integrated method, the media were unacknowledged, and market access and input are constraint factors while technical assistance and source of seed are most likely convenient factors. In order to promote the reliable extension methodologies in Myanmar, the policy makers should try to be more familiar to the media and farmer-field-school to farmers as field day, on farm-trial and demonstration.
\end{abstract}

\section{Keywords}

Impact assessment, extension program, hybrid rice, adoption, Myanmar

\section{Rationale and Problem Statement}

The Republic of the Union of Myanmar has a plan include the eight agendas have been implemented in Township level to the nation-wide level for rural development and poverty alleviation. From those agendas, "Increasing of 
High Productivity Growth" has been still carried responsibility by Ministry of Agriculture, Livestock and Irrigation (MOALI) for development of agricultural production sector. Research and Development is one of the main tasks under Department of Agriculture (DOA)[1-4]. Extension Division (ED), under Department of Agriculture (DOA), formulated some objectives based on related one agenda for rural development and alleviated poverty, Those are 1); to increase the yield per acre for all agricultural producers, good agricultural practices were practically undertaken by all farmers, 2); to produce and distribute the improved seed of various crops for adaptable with local weather condition in the large government manufacturing, 3); to extend the cultivated areas of special high yielding variety and high quality variety, 4); to extend the cultivated areas of cereal crop, oil seed crop, pulses and utensil crops for consumer to be secure, 5); to made show the farm trial and demonstration plots those are adaptable cropping patterns and agricultural practices with local climate condition, 6); to extend the growing areas of new crops, 7); to improve capacity building of Department of Agriculture's staff including advanced agricultural technologies. In these objectives mentioned except no (6), the rest all are generally related with the seed multiplication and distribution of hybrid rice. Besides, almost all of research activities are centered on Extension Division that organized with versatile agricultural specialists. In addition, these specialists are most likely providing research activities such as on-farm trials, demonstration sites, trainings and workshops, field days and farmer field schools, and multi-media to distribute the new innovation technology to remote areas in the nation. Nowadays, the arable lands were reduced due to increasing of population growth rate along with an abundance of industries. Therefore, to ensure the food security and better ways for getting highest yields in narrow areas were enhanced for seeking doing research[5-6].

Hybrid variety is one of four groups of rice varieties (high yielding variety, hybrid variety, high quality variety and traditional variety) in Myanmar (Denning, 2013). The yield of hybrid rice is 30\% more than the local variety and currently cultivated high yielding variety in Myanmar, besides could be successful 200 baskets (potential yield) per acre if had systematic and proper care (Win, 2015). Rice yields and farmers' income therefore would be increased by altering production of hybrid rice, consequently results are alleviating of poverty and better living standard of Myanmar farmers due to its higher yield is directly proportionate to farmers' farm income. For superior output, Pearl Thwe was chosen for hybrid rice seed production in Myanmar. For example; one variety of Pearl Thwe, $\mathrm{GW}_{1}$ variety has the special characteristics such adaptable for local condition, unusual productivity, eating good quality and better grinding quality when comparing with exemplary rice varieties as Sin Thu Kha, Manawthukha, A Yar Min and Thee Htet Yin (Win, 2015)[7-9].

Above mentioned consequently causes, Pearl Thwe was created in hybrid rice seed production in ShweTaung seed farm firstly, in Mandalay Region in Myanmar by government in monsoon season in 2011/2012, later gradually by farmers and company. Generally, the sown area of Pearl Thwe increased yearly but the growth rate (GR\%) increased with decreasing rate within four years, from 2011/2012 to 2014/2015 as shown in Table 1. Therefore, it is needed to examine the extension program, how much impact of each extension methodology? And which extension methodologies are really effective? on Pearl Thwe hybrid rice adoption in Myanmar[10-11].

Table 1. Sown area and growth rate (GR \%) of different rice groups in Myanmar

\begin{tabular}{|c|c|c|c|c|c|c|c|c|c|c|}
\hline \multirow{2}{*}{ No } & \multirow{2}{*}{ Year } & \multirow{2}{*}{$\begin{array}{c}\text { Total Rice } \\
\text { Sown area } \\
\text { (hectare) }\end{array}$} & \multicolumn{2}{|c|}{ Hybrid Variety } & \multicolumn{2}{|c|}{ High Yieldig Variety } & \multicolumn{2}{|c|}{ High Quality Variety } & \multicolumn{2}{|c|}{ Traditional Variety } \\
\hline & & & $\begin{array}{c}\text { Sown area } \\
\text { (ha) }\end{array}$ & $\begin{array}{l}\text { GR } \\
(\%)\end{array}$ & $\begin{array}{c}\text { Sown area } \\
\text { (ha) }\end{array}$ & GR (\%) & $\begin{array}{c}\text { Sown area } \\
\text { (ha) }\end{array}$ & $\begin{array}{l}\text { GR } \\
(\%)\end{array}$ & $\begin{array}{c}\text { Sown area } \\
\text { (ha) }\end{array}$ & $\begin{array}{l}\text { GR } \\
(\%)\end{array}$ \\
\hline 1. & $2011 / 2012$ & $6,529,370$ & 76,078 & & $3,851,454$ & & $1,046,053$ & & $1,555,786$ & \\
\hline 2. & $2012 / 2013$ & $6,293,136$ & 79,801 & 4.89 & $3,528,768$ & -8.38 & $1,197,529$ & 14.48 & $1,487,038$ & -4.42 \\
\hline 3. & $2013 / 2014$ & $6,225,610$ & 90,193 & 13.02 & $3,451,091$ & -2.20 & $1,256,856$ & 4.95 & $1,427,470$ & -4.01 \\
\hline 4. & $2014 / 2015$ & $6,231,159$ & 101,478 & 12.51 & $3,490,503$ & 1.14 & $1,253,356$ & -0.28 & $1,385,824$ & -2.92 \\
\hline
\end{tabular}

Source: Extension Division (2012, 2013, 2014) and Rice Division (2015). Remark: Pear Thwe rice adoption in 2011/2012 is in summer season. 


\section{Material and Methods}

Nowadays, many agricultural research systems comprise both of on-farm and on-station research because of detaining constant factors along the research process. To measure the economic effects in agricultural research, estimation by economic theory will be provided for the logical decision-making. For priority setting, the economic assessment of the effects of a given research program or set of program options and the evaluation of those effects are fundamental factors. The results of priority setting exercises for research may suggest modified research programs (Alaston et al., 1995). Adoption rate is also one of the future benefits in ex ante analysis. Ex ante analysis is designed to help set priorities, allocate resources, and decide whether or not to proceed with a specific agricultural research and extension program (Horstkotte-Wesseler et al., 2000).

Cost-benefit ratios are calculated to place a value on the extra output or the inputs saved (cost reductions) because of research. Ex-ante research evaluation and priority-setting analyses that relate to research yet to be done can use results from econometric analyses to provide a benchmark for the magnitude of supply-curve shifts in economic surplus models (Alaston et al., 1995). Extension expenditures (cost side) are not easily allocated to specific crops, farming systems, or recommendations; and separating the project from non-project impacts (benefit side) is challenging. In cost-effectiveness analysis, the benefits are measured in non-monetary units (such as the number of farmers receiving services or the number of trainees) and consist of improvements in several areas (such as in farmer education, technology adoption by farmers, and information dissemination). Cost-effectiveness analysis is always comparative (Cellini and Kee, 2010).

Moreover, the principal benefits of many activities in agricultural extension are not easily quantified in monetary terms (Cellini and Kee, 2010). In this study also, Cost and Benefit ratio was re-generated to apply from Cost and Benefit Analysis (CBA) in practically because this study did not calculate the cost (monetary value) of extension program, just accurately compute "performance times" and "number of participation by farmer" on extension program to analyze the benefit-cost ratio $(\mathrm{B}: \mathrm{C})$.

For Cost and Benefit ratio;

$$
\text { Benefit Cost Ratio (BCR) }=\frac{\text { Total Benefit }(\text { adoption area })(T B)}{\text { Total Cost }(\text { performance tiimes and participated farmers })(\text { TC) }}
$$

where;

$\mathrm{BCR}=$ Benefit-Cost ratio of Pearl Thwe hybrid rice adopted area and Extension Program

$\mathrm{TB}=$ Total Benefit (Pearl Thwe hybrid rice adopted areas)

TC = Total Cost ("performance times" and "participated farmers" in field trial (on-farm trial), demonstration, training, workshop, field day, farmer-field-school, the media, group discussion, integrated extension method and other extension method).

The second portion in this study is to estimate the individual extension method of extension program by estimating the marginal effect between two groups (Successful and Less-successful on Pearl Thwe rice adoption) through linear regression model.

This model is transformed into the logistic regression model by a linear function of explanatory variable:

$$
\begin{aligned}
\operatorname{Ln}\left(Y_{0,1}\right)= & \partial+\alpha_{1} \text { TotExt }+\alpha_{2} \text { PTExp }+\beta_{1} \text { FTrial }+\beta_{2} \text { Demo }+\beta_{3} \text { Train }+\beta_{4} \mathrm{WS}+\beta_{5} \text { FDay }+ \\
& \beta_{6} \text { FFS }+\beta_{7} \text { Media }+\beta_{8} \text { GD }+\beta_{9} \text { Inte }+\beta_{10} \text { Other }
\end{aligned}
$$

Where;

$$
\begin{aligned}
& \operatorname{Ln}\left(Y_{1}\right)=\text { Successful of extension methods for Pearl Thwe rice adoption } \\
& \operatorname{Ln}\left(Y_{0}\right)=\text { Less-successful of extension methods for Pearl Thwe rice adoption }
\end{aligned}
$$

ə, $\alpha \beta$ are coefficient estimates of explanatory variables such as field-trial, demonstration, training, workshop, field day, farmer-field-school, the media, group discussion, integrated extension method and other extension method.

\section{Sampling Design}

This study used the random sampling method through choosing the success and less-success of extension program 
depend on Pearl Thwe hybrid rice adoption areas in Myanmar. Nay Pyi Taw Council area and Bago Region (the best adoption areas) as the succeed areas, and Kayah State and Yangon Region as also the less-success areas selected to represent in this study. The 580 seasonal sample sizes were collected from 58 Township Officers in four State and Regions.

\section{What is the Agricultural Extension?}

The first modern extension service was started in Ireland during the potato famine in 1845 . The word extension derives from an educational development in England during the second half of the nineteenth century. The dissemination of relevant information and advice are reached to farmers. The American System is one of the older models of extension that has proved very successful in certain areas. This model is also known as 'transfer of technology' because technology is developed on research stations and universities and then transferred through extension agents to farmers (Ponniah et al., 2008). Agricultural extension activities were officially called advisory services in the United Kingdom and European countries, extension services in United States and Canada (Luukkainen, 2012). Four essential factors of the extension process are 1); knowledge and skills, the former is farmers which should do or not, and how can be used for continuous process and the latter one is to learn technical skills of how to use new technology for increasing crop yield: 2); technical advice and information what to help farmers for improving productivity up to advice, and making the decision on credit, prices and markets based on information: 3); structure and develop organizations to show farmers' interests and, take joint action for dissemination of knowledge and skills: 4); encourage motivation and self-confidence to farmer for changing things and making decisions to take initiative (Oakley and Garforth, 1985).

All the extension strategies attempted so far in the country are basically, top-down approaches, Researchers and extension workers are considered to be superior to the farmers in designing the required technological interventions. The extension services were exercised with a trial and error style preoccupied with more short-term objectives. In this respect, the activities of the prevailing extension program are not very different from that of its predecessors. The package extension program is considered as a panacea, as if it can work everywhere in the country (Wale, and Yalew, 2007).

More importantly, the number of participating farmers in the package program is taken as an evaluation criterion of success. Extensions agents are evaluated and promoted based on the number of farmers have managed to involve in the package, not the impact of the package on farmers' agricultural productivity and livelihoods. Some studies have shown that the achievements in yield and profits for those that are involved in the extension program do not seem to be significantly better than those that are not involved in the program (Nigussie and Mulat, 2003) in (Wale and Yalew, 2007). Thus, technologies have to be evaluated based on their livelihood impacts, not the number of participating farmers which assumes pre-emptively that the technologies are superior to farmers' practices (Wale and Yalew, 2007). For a long time, development of agriculture in developing countries mainly consisted of farmers and communities being told what to do, often by institutions and agents who have not taken sufficient time to understand their real needs and practices. Over the last two decades, government and nongovernmental organizations have recognized the need to move away from instruction and blue print solutions, towards more participatory approaches which involve communities in setting and fulfilling their own development goals and solutions. Hence, the system-oriented and participatory approaches are being increasingly integrated into the emerging research and development (R\&D) paradigm (Ponniah et al., 2008).

The environment of agricultural extension has been changing with more focus on food and nutrition security, poverty alleviation, entry of new actors such as the private sector and NGOs in the delivery of extension services, changed research and development paradigms and bottom-up approaches for end user involvement in decision-making. However, while the public spending on extension has been shrinking, the role of government in extension services delivery is also being examined, sometimes separating the financing of extension programs from the delivery of extension services. Alongside a new approach has been emerging: considering extension as facilitation and producers (farmers) as clients, sponsors and stakeholders rather than beneficiaries. The key trends reflect global socioeconomic change and driven by key concepts such as participation, client orientation, decentralization as well as developments in modern information and communication technology.

The design of agricultural extension programs in developing countries has been the subject of heated debate. Guided by these debates, extension services have undergone several transformations in the past few decades (Hussain, Byerlee and Heisey, 1994) in (Ponniah, 2008). In this part of the source book an attempt is made to trace the historical evolution of extension system/services. Then the generic problems of extension and the steps undertaken to address these problems 
are discussed. The following section reviews the various approaches used in disseminating information and knowledge. Finally, the changing roles and emerging challenges are discussed (Ponniah, 2008).

\section{Results and Discussion}

\subsection{Agricultural Extension in Myanmar}

At present in Myanmar, among operating various extension methods, extension staffs improved transferring advanced technology to farers by doing research activities through extension methodologies such as a); on-farm trials for variety, fertilizer application and Integrated Pest Management (IPM) for reaching towards optimum productivity, b); demonstration sites for showing the field results to decide for choosing advanced technologies, variety, kinds or dosage of organic and chemical fertilizer, controlling methods for pest and diseases, to catch right ways, c); trainings and workshops to transferring of new and advanced technologies by dissemination of knowledge and information, d); field days and farmer field schools to discuss practically detail in the fields level what farmers' needed to know, e); multimedia as channel, radio, television, edutainment, newspapers, magazines, booklets, posters and pamphlets to distribute the new innovation technology to remote areas in the nation.

Nowadays, most of the extension agents and subject matter specialists in Myanmar are interested in implementing a participatory extension approach instead of Selected Concentrative Strategy (SCS) and Training and Vist (T\&V) system in their extension programs. In accordance with 2015/2016 annual report of Extension Division, six persons for Ph.D, 52 for M.Sc, 1680 for B.Agr.Sc, 3961 for Diploma and 1035 for Agricultural High School have been servicing under Extension Division (including Head Office) by assisting Myanmar farmers in Nay Pyi Taw Council area and 14 States/ Regions.

\subsection{Descriptive Statistics of Township Officer's Characteristics and Farm Characteristics}

Township Officers were performed as the respondents in this study. This study is based on 80 and 280 samples of Pearl Thwe rice's successful adoption from eight Township Officers in Nay Pyi Taw Council area and 28 Township Officers in Bago Region, respectively. And 140 and 80 samples from Yangon Region and Kayah State were under less-successful adoption of Pearl Thwe rice, collected the former from 14 and the latter from eight Townships Officers, respectively. The samples were collected as monsoon and summer cultivated area separately from 2011/2012 to 2015/2016 in four State/Region based on the successful adopted area and less-successful adoption area.

Township Officers who are older were from successful adopted areas and Yangon Region which is increasing of Pearl Thwe rice sown area even if decreasing growth rate. Wale and Yalew (2007) focused the strategy which improvements in the productivity of small holder agriculture, on generation to improve agricultural technologies including innovation and adoption. This study for age is not consistent with the previous study. Officer with more overall experience have acceptable practices for the new innovation in both of successful adopted areas such Nay Pyi Taw Council area and Bago Region while the less experience in Yangon Regon and Kayah State. For Pearl Thwe rice experience has the indiscernible difference between successful and less-successful area for adoption, and may be neglect on it the reason is because of its familiarity with Pear Thwe rice just in five year in Myanmar. According to the comparison of total rice production area and Pearl Thwe rice production area based on the "mean" from descriptive statistics, Nay Pyi Taw Council area is around $5 \%$ for Pearl Thwe rice by total rice area and Yangon Region is less than 1\%, whilst Bago Region and Kayah State are over 1\% as shown in Table 2. In this result, Nay Pyi Taw Council area is the best because a lot of demonstrations and field trials were conducted as study tour or field visit by showing the contact farmers from all States and Regions.

Table 2. Characteristics of Township Officers and farm characteristics

\begin{tabular}{|c|c|c|c|c|c|c|c|c|c|c|c|c|c|c|c|}
\hline \multirow{2}{*}{ Variable } & \multicolumn{3}{|c|}{ Nay Pyi Taw } & \multicolumn{3}{|c|}{ Bago Region } & \multicolumn{3}{|c|}{ Yangon Region } & \multicolumn{3}{|c|}{ Kayah State } & \multicolumn{3}{|c|}{ Overall } \\
\hline & Mean & $\begin{array}{l}\text { Std. } \\
\text { Dev. }\end{array}$ & $\%$ & Mean & $\begin{array}{l}\text { Std. } \\
\text { Dev. }\end{array}$ & $\%$ & Mean & $\begin{array}{l}\text { Std. } \\
\text { Dev. }\end{array}$ & $\%$ & Mean & $\begin{array}{l}\text { Std. } \\
\text { Dev. }\end{array}$ & $\%$ & Mean & $\begin{array}{l}\text { Std. } \\
\text { Dev. }\end{array}$ & $\%$ \\
\hline $\begin{array}{l}\text { Age of } \\
\text { Township } \\
\text { Officer }\end{array}$ & 52.00 & 4.63 & & 49.57 & 6.99 & & 50.71 & 5.03 & & 46.88 & 6.51 & & 49.81 & 6.23 & \\
\hline
\end{tabular}


Table 2. cont.

\begin{tabular}{|c|c|c|c|c|c|c|c|c|c|c|c|c|c|c|c|}
\hline \multirow{2}{*}{ Variable } & \multicolumn{3}{|c|}{ Nay Pyi Taw } & \multicolumn{3}{|c|}{ Bago Region } & \multicolumn{3}{|c|}{ Yangon Region } & \multicolumn{3}{|c|}{ Kayah State } & \multicolumn{3}{|c|}{ Overall } \\
\hline & Mean & $\begin{array}{l}\text { Std. } \\
\text { Dev. }\end{array}$ & $\%$ & Mean & $\begin{array}{l}\text { Std. } \\
\text { Dev. }\end{array}$ & $\%$ & Mean & $\begin{array}{l}\text { Std. } \\
\text { Dev. }\end{array}$ & $\%$ & Mean & $\begin{array}{l}\text { Std. } \\
\text { Dev. }\end{array}$ & $\%$ & Mean & $\begin{array}{l}\text { Std. } \\
\text { Dev. }\end{array}$ & $\%$ \\
\hline $\begin{array}{l}\text { Pearl Thwe } \\
\text { experience } \\
\text { of Township } \\
\text { Officer }\end{array}$ & 2.50 & 1.31 & & 3.18 & 1.56 & & 3.07 & 1.27 & & 3.75 & 0.71 & & 3.14 & 1.38 & \\
\hline $\begin{array}{l}\text { Total rice } \\
\text { production } \\
\text { area }\end{array}$ & 11247.25 & 17009.24 & & 53983.00 & 55731.64 & & 42161.79 & 46800.85 & & 5104.36 & 9930.08 & & 38493.14 & 49510.85 & \\
\hline $\begin{array}{c}\text { Pearl } \\
\text { Thwe rice } \\
\text { production } \\
\text { area }\end{array}$ & 518.75 & 562.48 & 4.61 & 553.14 & 809.22 & 1.02 & 303.84 & 466.95 & 0.72 & 65.36 & 163.34 & 1.28 & 420.94 & 667.27 & 1.09 \\
\hline
\end{tabular}

Note: Characteristics of Townships Officer based on (58 sample size). Farm characteristics based on (seasonal 580 sample size).

\section{Hybrid Rice (Pearl Thwe) Adoption in Myanmar}

Pearl Thwe was firstly created in hybrid rice seed production in ShweTaung seed farm by government in monsoon season in 2011/2013, later gradually to other places such farmers and company in States and Regions as shown in Table 3. Firstly the government established Pearl Thwe hybrid rice seed production (211.74) hectare in 2011/2012, (148.58) hectare in 2014/2015 through (191.90) hectare in 2012/13, (158.70) hectare in 2013/2014, respectively, with decreasing seed generating hectare. Nevertheless, to begin with (501) hectare in 2011/2012, then dramatically increase till (805.67) hectare in monsoon season only in 2015/2016, on company sides. Even though decreasing and dramatically increase between the government and company sides, the seed production area by Myanmar farmers got steady situation within five years as shown in Table 3.

Table 3. Hybrid rice (Pearl Thwe) seed production in 2011/2012 - 2015/2016 in Myanmar

\begin{tabular}{lllllll}
\hline No & Year & $\begin{array}{l}\text { Government } \\
\text { (by DOA) (acre) }\end{array}$ & Farmer (acre) & Company (acre) & Total (acre) & Remark \\
\hline 1. & $2011 / 2012$ & $523(211.74)$ & - & $501(202.83)$ & $1,024(414.57)$ \\
2. & $2012 / 2013$ & $474(191.90)$ & $40(0.02)$ & $1,323(535.63)$ & $1,837(743.72)$ \\
3. & $2013 / 2014$ & $392(158.70)$ & $40(0.02)$ & $880(356.28)$ & $1,312(531.17)$ \\
4. & $2014 / 2015$ & $367(148.58)$ & - & $1,787(723.48)$ & $2,154(872.06)$ & Only monsoon \\
5. & $2015 / 2016$ & $99(40.08)$ & $40(0.02)$ & $1,990(805.67)$ & $2,129(861.94)$ & season \\
\hline
\end{tabular}

Source: Win, (2014/2015). Note: The digits in the parenthesis are hectare.

From the findings, Nay Pyi Taw Council area, Kachin State, Kayin State, Chin State, Tanintharyi Region, Bago Region and Magway Region are good annual average growth rate for Pearl Thwe hybrid rice $\left(\mathrm{F}_{1}\right)$ production. Kayah State, Rakhine State and Yangon Region adopted with decreasing to negative growth rate yearly, and the rest all State and Region are also less. Nevertheless, Sagaing Region, Mandalay Region, Mon State, Shan State and Ayeyarwaddy Region increased the adoption areas yearly even having decreasing growth rate as shown in Table 4. 
Table 4. Hybrid Rice (Pearl Thwe) Adoption in Myanmar

\begin{tabular}{|c|c|c|c|c|c|c|c|c|c|c|}
\hline \multirow[b]{2}{*}{ No } & \multirow{2}{*}{ Region/State } & \multicolumn{3}{|c|}{$2011 / 12-2012 / 13$} & \multicolumn{3}{|c|}{$2012 / 13-2013 / 14$} & \multicolumn{3}{|c|}{$2013 / 14-2014 / 15$} \\
\hline & & $\begin{array}{c}2011 / 12 \\
\text { (ha) }\end{array}$ & $\begin{array}{c}2012 / 13 \\
\text { (ha) }\end{array}$ & GR \% & $\begin{array}{c}2012 / 13 \\
\text { (ha) }\end{array}$ & $\begin{array}{c}2013 / 14 \\
\text { (ha) }\end{array}$ & GR \% & $\begin{array}{c}\text { 2013/14 } \\
\text { (ha) }\end{array}$ & $\begin{array}{c}2014 / 15 \\
\text { (ha) }\end{array}$ & GR \% \\
\hline 1. & Nay Pyi Taw & 953.85 & 2334.82 & 144.78 & 2334.82 & 3355.47 & 43.71 & 3355.47 & 5196.76 & 54.87 \\
\hline 2. & Kachin & 6.07 & 79.35 & 1206.67 & 79.35 & 183.00 & 130.61 & 183.00 & 758.70 & 314.60 \\
\hline 3. & Kayah & 21.86 & 220.65 & 909.26 & 220.65 & 563.56 & 155.41 & 563.56 & 474.09 & -15.88 \\
\hline 4. & Kayin & 6.88 & 108.10 & 1470.59 & 108.10 & 188.26 & 74.16 & 188.26 & 427.94 & 127.31 \\
\hline 5. & Chin & 4.05 & 58.70 & 1350.00 & 58.70 & 76.52 & 30.34 & 76.52 & 129.15 & 68.78 \\
\hline 6. & Sagaing & 446.56 & 2271.26 & 408.61 & 2271.26 & 3938.06 & 73.39 & 3938.06 & 4276.11 & 8.58 \\
\hline 7. & Tanintharyi & 12.15 & 87.45 & 620.00 & 87.45 & 125.10 & 43.06 & 125.10 & 222.27 & 77.67 \\
\hline 8. & Bago & 417.81 & 7806.48 & 1768.41 & 7806.48 & 8982.19 & 15.06 & 8982.19 & 12317.41 & 37.13 \\
\hline 9. & Magway & 202.43 & 1734.82 & 757.00 & 1734.82 & 2114.98 & 21.91 & 2114.98 & 3118.62 & 47.45 \\
\hline 10. & Mandalay & 285.02 & 1609.72 & 464.77 & 1609.72 & 5164.78 & 220.85 & 5164.78 & 6169.64 & 19.46 \\
\hline 11. & Mon & 19.03 & 183.81 & 865.96 & 183.81 & 279.76 & 52.20 & 279.76 & 345.34 & 23.44 \\
\hline 12. & Rakhine & 17.00 & 419.43 & 2366.67 & 419.43 & 565.59 & 34.85 & 565.59 & 411.74 & -27.20 \\
\hline 13. & Yangon & 387.04 & 3687.45 & 852.72 & 3687.45 & 5705.26 & 54.72 & 5705.26 & 4680.97 & -17.95 \\
\hline 14. & Shan & 182.59 & 1480.16 & 710.64 & 1480.16 & 2948.18 & 99.18 & 2948.18 & 4737.65 & 60.70 \\
\hline \multirow[t]{2}{*}{15.} & Ayeyarwaddy & 85.02 & 2470.75 & 2806.07 & 2470.75 & 6724.29 & 172.16 & 6724.29 & 10491.50 & 56.02 \\
\hline & Union & 3047.37 & 24552.94 & 705.71 & 24552.94 & 40914.98 & 66.64 & 40914.98 & 53757.89 & 31.39 \\
\hline
\end{tabular}

Source: Annual report by Rice Division. Remark: Pear Thwe rice adoption in 2011/2012 is only in summer season.

In addition, Bago Region and Ayeyarwaddy Region were the most adopted areas which Pearl Thwe rice were cultivated over $(12,000)$ hectare and $(10,000)$ hectare with increasing rate in 2014/2015 within four year while Mandalay Region, Nay Pyi Taw Council area, Shan State and Sagaing Region were over $(6,000)$ hectare, $(5,000)$ hectare, $(4,000)$ hectare and just over $(4,000)$ hectare, respectively. Even though Yangon Region was over $(4,000)$ hectare, it with decreasing rate and the rest all State and Region were under $(2,000)$ hectare adopted area, except Magway Region was over $(3,000)$ hectare adopted area in Myanmar as shown in Figure 1.

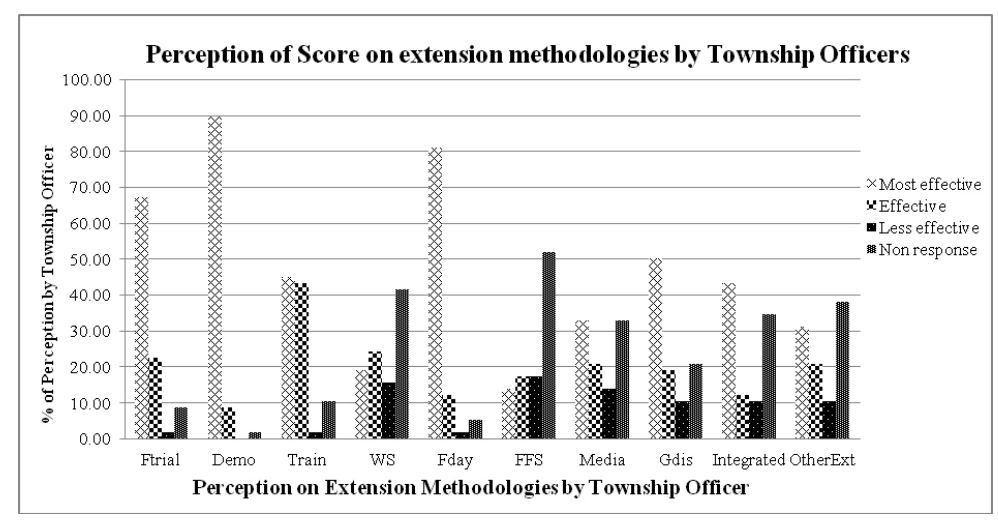

Figure 1. Perception of Score on extension methodologies by Township Officers 


\subsection{Benefit (Pearl Thwe adoption area) and Cost (applied extension methodologies) Ratio}

As shown in Table 5, there are still operating various extension methods in Myanmar such as field trial or on-farm-trial, demonstration, training, workshop, field day, farmer-field-school, the media, group discussion, integrated extension method and other extension method (traditionally). Using by these all methods were not the negative effect, it is therefore all methods of extension program have the benefit and affecting factors on Pearl Thwe rice adoption. In this case, the ratios were separated such as over the ratio of (150) is the first rank beneficial to Myanmar farmer through those of extension methods. Additionally, between (100 and 150) is second rank whereas under the ratio of (100) is unsatisfactory or third rank.

Table 5. Benefit and Cost Ratio of Pearl Thwe rice adoption and extension methodologies

\begin{tabular}{|c|c|c|c|c|c|c|}
\hline \multirow[t]{2}{*}{ No } & \multirow[t]{2}{*}{ Description } & \multirow[t]{2}{*}{$\begin{array}{l}\text { Obser- } \\
\text { ation }\end{array}$} & \multicolumn{2}{|c|}{$\begin{array}{l}\text { Ratio of Pearl Thwe and } \\
\text { Times of Extension Methods }\end{array}$} & \multicolumn{2}{|c|}{$\begin{array}{c}\text { Ratio of Pearl Thwe and } \\
\text { participated person in extension } \\
\text { methods }\end{array}$} \\
\hline & & & Ratio & Std.Err & Ratio & Std.Err \\
\hline 1. & $\begin{array}{l}\text { Times and farmer participated } \\
\text { in Field Trial }\end{array}$ & 129 & $155.35^{* * *}$ & 24.9694 & 98.03 & 15.2419 \\
\hline 2. & $\begin{array}{l}\text { Times and farmer participated } \\
\text { in Demonstration }\end{array}$ & 376 & $138.63 * *$ & 15.7253 & 12.84 & 2.6115 \\
\hline 3. & $\begin{array}{l}\text { Times and farmer participated } \\
\text { in Training }\end{array}$ & 275 & $25.53 *$ & 2.7711 & 0.39 & 0.0977 \\
\hline 4. & $\begin{array}{l}\text { Times and farmer participated } \\
\text { in Workshop }\end{array}$ & 41 & $61.98 *$ & 10.7886 & 1.14 & 0.1853 \\
\hline 5. & $\begin{array}{l}\text { Times and farmer participated } \\
\text { in Field Day }\end{array}$ & 311 & $199.97 * * *$ & 17.2124 & 2.14 & 0.1969 \\
\hline 6. & $\begin{array}{l}\text { Times and farmer participated } \\
\text { in Farmer-Field-School }\end{array}$ & 10 & $119.35^{* *}$ & 38.2836 & 1.26 & 0.3712 \\
\hline 7. & $\begin{array}{l}\text { Times and farmer participated } \\
\text { in Media }\end{array}$ & 92 & $164.88 * * *$ & 28.1488 & 0.96 & 0.1882 \\
\hline 8. & $\begin{array}{l}\text { Times and farmer participated } \\
\text { in Group Discussion }\end{array}$ & 122 & $21.96^{*}$ & 4.8948 & 1.12 & 0.1969 \\
\hline 9. & $\begin{array}{l}\text { Times and farmer participated } \\
\text { in Integrated Extension }\end{array}$ & 13 & $80.95^{*}$ & 22.5924 & 5.52 & 2.4549 \\
\hline 10 & $\begin{array}{l}\text { Times and farmer participated } \\
\text { in Other Extension }\end{array}$ & 46 & $57.71 *$ & 11.7251 & 1.23 & 0.2883 \\
\hline
\end{tabular}

Note: Data based on (seasonal 580 sample size).

\subsection{Field day, The Media and Field-trial}

In Table 5, the results show that field day, media and field-trial are the best benefit cost ratio of $(199.97,164.88,155.35)$ respectively, to show and distribute the best applied ways all inclusive in advanced technologies, proper management, adequate amount and recommend dosage of chemical industry such as fertilizer, pesticides, insecticides and herbicides. The field day and, the media as radio, television, farmer channel, magazine, the agri-business journal, pamphlet, handbook, vinyl, motto and slogan suchlike are occasionally simultaneously but sometimes separate each other. Anyhow, both of them were normally followed after being the field trials. Field day is an overall most impressive approach among extension methodologies by the benefit (Pearl Thwe adopted area) cost (applied extension methodologies) ratio. The reason is the position of benefit and cost ratio is the first rank in Nay Pyi Taw Council area and Bago Region, the second rank in Yangon Region (less-successful) too as shown in (Table 5) and (Table 6). For the field-trial approach, all the rest study areas except Kayah State, preferred field-trial is proved a theory by experiment, based on the situation of "Seeing is Believing", as shown in (Table 6). The media approach in Bago Region is the first rank but not mentioned by Nay Pyi Taw Council area and, unsatisfactory approach by both of the rest two also, as shown in (Table 6). 
Table 6. Cost and Benefit Ratio of Hybrid Rice (Pearl Thwe) Adoption in Myanmar

\begin{tabular}{|c|c|c|c|c|c|c|}
\hline \multirow{2}{*}{$\begin{array}{l}\text { Extension } \\
\text { Methodologies }\end{array}$} & \multirow{2}{*}{ Region } & \multirow{2}{*}{$\begin{array}{l}\text { Obser- } \\
\text { vation }\end{array}$} & \multicolumn{2}{|c|}{ Ratio with the time } & \multicolumn{2}{|c|}{$\begin{array}{l}\text { Ration with the } \\
\text { participated person }\end{array}$} \\
\hline & & & Ratio & Std.Err & Ratio & Std.Err \\
\hline \multirow[t]{4}{*}{ Field Trial } & Nay Pyi Taw & 4 & $585.50 * * *$ & 429.1266 & 585.50 & 429.1266 \\
\hline & Bago Region & 48 & $229.11 * * *$ & 47.3584 & 103.37 & 22.8695 \\
\hline & Yangon Region & 55 & $169.29 * * *$ & 40.2287 & 136.99 & 32.8094 \\
\hline & Kayah State & 22 & 17.68 & 3.9951 & 14.57 & 3.0875 \\
\hline \multirow[t]{4}{*}{ Demonstration } & Nay Pyi Taw & 48 & $262.26^{* * *}$ & 47.2181 & 15.41 & 2.4735 \\
\hline & Bago Region & 209 & $159.02 * * *$ & 20.6417 & 14.58 & 4.6923 \\
\hline & Yangon Region & 89 & 70.34 & 19.1707 & 7.80 & 2.3169 \\
\hline & Kayah State & 30 & 70.14 & 25.4340 & 8.33 & 5.1995 \\
\hline \multirow[t]{4}{*}{ Training } & Nay Pyi Taw & 14 & $141.38 * *$ & 43.7108 & 2.46 & 0.7779 \\
\hline & Bago Region & 197 & 32.55 & 3.5328 & 0.38 & 0.1210 \\
\hline & Yangon Region & 39 & 8.18 & 1.7990 & 0.23 & 0.0771 \\
\hline & Kayah State & 25 & 39.80 & 12.3222 & 0.72 & 0.2394 \\
\hline \multirow[t]{3}{*}{ Workshop } & Nay Pyi Taw & 10 & 79.28 & 17.8158 & 1.50 & 0.2134 \\
\hline & Bago Region & 13 & 88.56 & 32.4404 & 1.58 & 0.5133 \\
\hline & Kayah State & 18 & 31.46 & 7.7066 & 0.57 & 0.1800 \\
\hline \multirow[t]{4}{*}{ Field Day } & Nay Pyi Taw & 32 & $531.36^{* * *}$ & 99.8769 & 4.91 & 1.0994 \\
\hline & Bago Region & 171 & $212.46 * * *$ & 23.7433 & 1.92 & 0.2290 \\
\hline & Yangon Region & 75 & $147.45^{* *}$ & 24.7608 & 2.24 & 0.4194 \\
\hline & Kayah State & 33 & 57.97 & 16.3583 & 1.32 & 0.3575 \\
\hline $\begin{array}{l}\text { Farmer Field } \\
\text { School }\end{array}$ & Bago Region & 10 & $119.35^{* *}$ & 38.2836 & 1.26 & 0.3712 \\
\hline \multirow[t]{3}{*}{ Media } & Bago Region & 37 & $294.10 * * *$ & 70.7135 & 1.22 & 0.3564 \\
\hline & Yangon Region & 47 & 82.98 & 9.8462 & 0.62 & 0.0908 \\
\hline & Kayah State & 8 & 9.64 & 4.4496 & 0.55 & 0.3645 \\
\hline \multirow[t]{3}{*}{$\begin{array}{l}\text { Group } \\
\text { Discussion }\end{array}$} & Bago Region & 62 & 19.49 & 5.4688 & 1.13 & 0.2643 \\
\hline & Yangon Region & 39 & 39.19 & 6.6802 & 1.24 & 0.2043 \\
\hline & Kayah State & 21 & 16.93 & 4.6283 & 0.57 & 0.1313 \\
\hline \multirow{3}{*}{$\begin{array}{l}\text { Integrated } \\
\text { Extension } \\
\text { Methods }\end{array}$} & Bago Region & 6 & $137.26^{* *}$ & 56.2365 & 3.41 & 2.0293 \\
\hline & Yangon Region & 6 & 54.44 & 16.1578 & 26.13 & 7.7557 \\
\hline & Kayah State & 1 & 19.00 & 0.0000 & 0.68 & 0.0000 \\
\hline \multirow[t]{3}{*}{$\begin{array}{l}\text { Other Extension } \\
\text { Methods }\end{array}$} & Bago Region & 12 & $168.61 * * *$ & 51.9009 & 9.67 & 3.2661 \\
\hline & Yangon Region & 15 & 44.55 & 11.0172 & 0.63 & 0.1395 \\
\hline & Kayah State & 19 & 26.58 & 5.1950 & 0.71 & 0.1476 \\
\hline
\end{tabular}

Note: Based on seasonal 580 sample sizes in 2011/2012 to 2015/2016.

\subsection{Demonstration and Farmer-field-school}

The benefit cost ration of 138.63 and 119.35 are also satisfied by demonstration and farmer-field-school as shown in Table 5. Most of farmer mostly like and interested in demonstration plot after being the field-trials, to see the field 
results reality and information too. From that, contact and neighboring farmers can arrange and manage, and comply by advanced technologies, the new innovation crops and modern practices in their field practically. Furthermore, some farmers can visit several times to the demonstration plots if they had unclear factors, conflict and some misunderstanding information between traditionally and modern. Extension can demonstrate the feasibility of sustainable practices to farmers as the tools for observation and to train them to monitor the situation on their own farms (Wale and Yalew, 2007). Therefore, this study is also related with previous extension study.

Farmer-field-school is also one of important extension methods to disseminate of agricultural knowledge and information and to solve the problems and constraints of farmers. At present in Myanmar, there are built in Nay Pyi Taw Council area as the Knowledge Centers (KC) under Fostering Agricultural Revitalization in Myanmar-FARM Project - (International Fund for Agricultural Development) IFAD. (Brouwers and Roling 1999) also recommended that sharing of knowledge for sustainable agriculture, extension staffs must make use of farmers' knowledge and work together with them because indigenous practices and experimentation of farmers can be an important 'entry point' for introducing sustainable farming practices. Extension workers should seek to understand the learning process, provide expert advice where required, convene and create learning groups, and help farmers overcome major hurdles in adapting their farms (Wale and Yalew, 2007). Therefore, farmer-field-school approach of extension methodologies in this study is no deviation from previous observations.

\subsection{Training, Workshop, Group discussion, Integrated Extension Methods and Other Extension Methods}

The results showing of training, workshop, group discussion, integrated extension method and other extension methods involved as unsatisfactory methodologies in this study as shown in Table 5. Farmers normally don't have time to attend and participate in training the reason is because they spent all of their time in the field due to the succession of the seasonal crops. In addition, farmers think that they could not compensate by the training, for their time in the field what they wanted to spend for succession of the year-round crops. Except farmers in Nay Pyi Taw Council area thinks the training is also an important extension approach because they always keep in touch with not only the village extension staff officers but also Township to District to Regional Officer to higher official levels of head office, due to the high ranking official areas of the nation as shown in Table 6. Therefore, the farmers in that area changed their mind-set on training approach of extension methodologies.

In accordance with the outlook of farmers in Kenyan, they told that they were not receiving advice from this training and visit (T\&V) system, despite a supposedly improved system (Gautam, 2000). Morris et al. (1999) also found that Training and Visit $(\mathrm{T} \& \mathrm{~V})$, like the general extension approach mainly relied on contact farmers and tended to neglect the larger rural population. Therefore, this method was characterized by limited feedback from farmers because of not flexible enough to meet the needs of the large variety of farming systems. Therefore, this study is normally consistent with the other studies.

The effects of group discussion and workshop in this study showed that unsatisfactory situation as shown in Table 5, the reason is because the group discussion approach (or participatory approach for all inclusive both of extension staffs and farmers) and workshop approach are now inaccessible to the Myanmar farers. They think these approaches may be deviation from their determination on their farm allocation including crops, agricultural practices, inputs usage, time management and suchlike. Cho (2002) said that most of the extension agents and subject matter specialists in Myanmar are interested in participatory extension approach, and had a plan to implement practically at the ground level. This study therefore consistent with the previous one the reason is because of point of similarity between two studies.

The results showed for integrated extension methodology that the second rank in Bago Region but not unresponsive in Nay Pyi Taw Council area and, both of the less-successful areas were unsatisfactory levels as shown in Table 6. Wale \& Yalew (2007) recommended that new agricultural extension program which essentially emphasizes the package approach what based on critical evaluation of extension efforts in the past, as contemporary extension program. This study therefor is not consistent with the study of Wale and Yalew (2007).

For other extension methods in this study intended that some Township Officer have the creation power how to organize the farmers for all inclusive?, how to approach and transfer the technology to farmers?, they know very well to establish the effectiveness and efficient extension program by traditional extension approach. For example, it was created as the authority persons who may be Monks and Bishops under religions attention and the respectful older persons in the whole village, by extension staffs and officers. The reason is everybody worships and admires them in the village 
level to village tract level. By those authority persons can help extension staffs and officers to reach their terminal goal points. In accordance with the survey data, Bago Region only has the first rank to apply the other extension methods for decision making of Pearl Thwe rice adoption as shown in Table 6. Nay Pyi Taw Councial area and the less-successful adopted areas were not mentioned and unsatisfactory situation, respectively.

By the perception of Township Officer, demonstration and field day were the most effective methods, and fieldtrial, training and group discussion were effective extension methods for successful on Pearl Thwe rice adoption. But farmer-field-school, workshop, other extension methods, integrated extension method and media were the most unacknowledged factors by the percentage of perception of Township Officer in this study as shown in Figure 1.

As the result showed that technology assistance and source of seed did not have the constraint to success for Pearl Thwe rice adoption, and input such as labor, chemical and organic fertilizers, pesticides, insecticides, herbicides and suchlike.., and investment were less constraint for Pearl Thwe rice adoption to success. For market access, normally it was the constraint as shown in Figure 2.

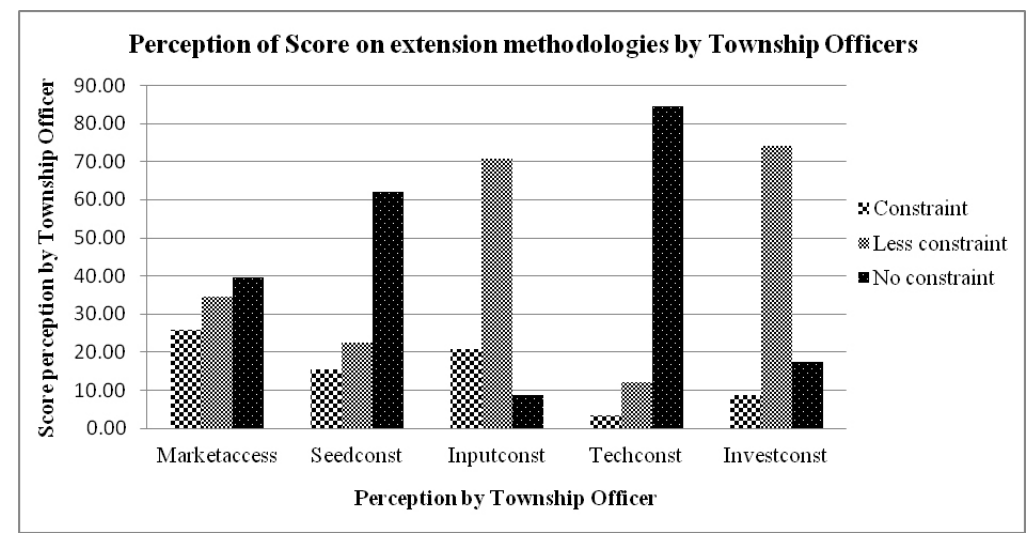

Figure 2. Perception of Score on extension methodologies by Township Officers

\subsection{Marginal effect of the characteristics of Township Officers}

Total experience of Township Officers was a significant factor in this study. The reason is the Township Officer with more experience could be able to approach effectively on practically applied extension methods for Pearl Thwe rice adoption at 10\% significant level with positive effect as shown in Table 7 . Nothing but Pearl Thwe experience of Township Officers did not both of positive and negative effect on adoption for Pearl Thwe rice because the extent of Pearl Thwe production period in Myanmar was just in five years, from 2011/12 to 2015/16.

\subsection{Marginal effect of extension methods by the perception of Township Officers}

Among extension methodologies, demonstration, workshop, field day, farmer-field-school, group discussion, integrated extension methods and other extension methods were highly significant with positive effects at $1 \%$ level to be successful adoption rate on Pearl Thwe hybrid rice production in Myanmar, as shown in Table 7. But training and the media methods of extension methodologies were not affecting factors on whether successful for Pearl Thwe rice or not. An amazing factor in this study that the field-trial was effecting on successful and less-successful of Pearl Thwe rice adoption with negative effect at $1 \%$ highly significant level, this mean that Township Officers disliked to perform fieldtrial in their Township even accepting the best benefit cost ratio (B:C).

In Table 7 showed that market access of Pearl Thwe rice was significant at 5\% level, with positive effect, to success Pearl Thwe rice adopted area mostly. Constraints of seed and input were not touch to significant level in this study. Nevertheless, technology constraint and investment constraint were highly significant at 1\% level and significant at $10 \%$, respectively.

In practically at ground-survey data, Pearl Thwe rice has "pros and cons". The advantage points of Pearl Thwe rice are actual yield increasing (eg/may be virtually (200 basket) per acre or (10.31 MT)/ha if had proper management), shorter life span (eg/only around 110 days for hybrid rice), less water requirement due to shorter life span along the growing season. The disadvantage points of Pearl Thwe rice are vulnerable to bacterial leaf blight (BLB) and bacterial leaf sheet (BLS), poor eating quality due to the less of amylose percent what leading to dislike of local people in Myanmar, a few 
demand in local market because of the quality and unstable price.

Table 7. Marginal effect of the characteristics of Township Officers and extension methods by the perception of Township Officers

\begin{tabular}{llll}
\hline Vairable & Definition & Marginal effect & Std. Err. \\
\hline \multicolumn{3}{c}{ Characteristics of Township Officers } \\
\hline Totalexp & Totaal experience of Township Officer & $0.0149^{*}$ & 0.0089 \\
PTexp & Pearl Thwe experience of Township Officer & -0.0364 & 0.0471 \\
\hline \multicolumn{2}{c}{ Extension methods by the perception of Township Officers } \\
\hline FTrial & Field Trial by perception of Township Officers & $-0.1859^{* * *}$ & 0.0552 \\
Demo & Demonstration by perception of Township Officers & $0.6316^{* * *}$ & 0.1528 \\
Train & Training by perception of Township Officers & 0.0771 & 0.0556 \\
WS & Workshop by perception of Township Officers & $0.1472^{* * *}$ & 0.0432 \\
FDay & Field Day by perception of Township Officers & $0.6667^{* * *}$ & 0.0747 \\
FFS & Farmer-field-school by perception of Township Officers & $0.4058^{* * *}$ & 0.0440 \\
Media & Media by perception of Township Officers & -0.0429 & 0.0403 \\
GDis & Group Discussion by perception of Township Officers & $0.2186^{* * *}$ & 0.0420 \\
Integrated & Integrated extension method by perception of Township Officers & $0.1643^{* * *}$ & 0.0398 \\
OtherExt & Other extension method by perception of Township Officers & $0.1119^{* * *}$ & 0.0401 \\
Market & Market access of Pearl Thwe rice by perception of Township Officers & $0.1178^{* *}$ & 0.0458 \\
Seed & Seed constraint by perception of Township Officers & 0.0480 & 0.0415 \\
Input & Input constraint by perception of Township Officers & 0.0580 & 0.0498 \\
Techno & Technology constraint by perception of Township Officers & $0.6429^{* * *}$ & 0.1073 \\
Investment & Investment constraint by perception of Township Officers & $0.0958^{*}$ & 0.0533 \\
\hline Not* is & & & \\
\hline & & & \\
\hline
\end{tabular}

Note: $*$ is the significant level at $10 \%, * *$ is the significant level at $5 \%$ and $* * *$ is the significant level at $1 \%$. Data based on the 58 respondents (Township Officers).

\section{Conclusion and Recommendations}

\subsection{Conclusions}

In Myanmar, extension program included the most important agricultural extension methods such as field-trial, demonstration, training, workshop, field day, farmer-field-school, media, group discussion, integrated extension method and other extension method. Among those all methods, one or some or almost methods were applied in each State and Region based on preference of local farmers[13-14].

Especially, demonstration and field day were the best extension methods by overall determinations which are benefitcost-ratio (B:C), marginal effect (ME) by the perception of Township Officers, score rating assessment by the perception of Township Officers. Field-trial was also the best benefit-cost-ratio (B:C) and the most effective extension method but negative effect for successful to adopt of Pearl Thwe rice. That means most of Township Officers not prefer to perform the field-trial due to the highest cost the reason is field-trial such as variety, fertilizer, agricultural practices including crop establishment and new technology and new crop innovation, integrated pest management (IPM) and suchlike trials 
are very expensive. In consequence of the lack of field-trial, would be faint the demonstration and field day extension methods because these two methods normally connected with field-trial strongly.

Farmer-field-school extension method was created by only Bago Region and Township Officers pay the most attention as unacknowledged extension method even the best $(\mathrm{B}: \mathrm{C})$ ratio. The reason is this methodology is not familiar with both of the local farmers and Township Officer too, in Myanmar. Workshop was unsatisfactory (B:C) ratio in study areas, and the second most unacknowledged extension method even have the highly significant with positive effect. And also training, was unsatisfactory (B:C) ratio except in Nay Pyi Taw Council area with nothing positive or negative effect on Pearl Thwe rice adoption successfully. The media was also nothing both of positive and negative effect and over (30\%) of perception of Township Officers with non-response, but highly satisfied method in only Bago Region[15-16].

Group discussion was unsatisfactory (B:C) ratio but with positive effect on Pearl Thwe rice adopted area even nonresponse by Nay Pyi Taw Council area. Both of integrated and other extension methods were preferred to (B:C) ratio by only in Bago Region, and positive effects for Pearl Thwe rice adoption but unacknowledged extension methods by only Nay Pyi Taw Council area.

Farmer-field-school, media, group discussion, integrated and other extension methods were not performed in Nay Pyi Taw Council area while the rest all are inclusive actions. In Bago Region, all inclusive extension methods were performed. Less-successful Pearl Thwe rice adoption areas such Yangon Region and Kayah State did not have the farmer-field-school while the rest all extension methods are inclusive.

\subsection{Recommendations}

In order to promote the extension program in Myanmar, Extension Division (ED), Department of Agriculture (DOA), Ministry of Agriculture, Livestock and Irrigation (MOALI) should provide the field-trial experimental plots as much as they (Township Officer) cost. The policy maker should build the farmer-field-school likes Knowledge Center (KC) under FARM project, IFAD, and enhance the group discussion in order to leading to "participatory approach" in Myanmar. Should be extend and do familiar with the trainings to disperse the information quickly in short time, then towards "training for trainer" (TOT). Policy makers should be continued for maintenance of demonstration and field days.

\section{Acknowledgement}

Authors have a special thanks to Department of Agriculture (DOA), Ministry of Agriculture, Livestock and Irrigation for arrangements of evolutionary process within my survey period in Myanmar, and Dr. Orachos Napasintuwong, Department of Agricultural and Resource Economics, Faculty of Economics, Kasetsart University, Thailand for provision of Conference fee and accommodation along the period of Asian Society of Agricultural Economists (ASAE) Conference, in Bangkok, Thailand. Besides, the authors honestly thank to Graduate Education and Institutional Development Department (GEIDD), SEAMEO SEARCA for publication fee in the "International Journal of Food Science and Agriculture".

\section{Reference}

[1] Alaston, J. M., G.W. Norton, P.G. Pardey, M. Morris, M. Alvarez, J. Corven and A. Moral Rama. (1995). Science under scarcity: principles and practice for agricultural research evaluation and priority setting. Cornell University Publishing.

[2] Cellini, S. R and J. E. Kee. (2010). Cost-effectiveness and cost-benefit analysis. Handbook of practical program evaluation.Retrieved from: http://supportlocaleconomy.com/wp-content/uploads/2015/12/74-Cost-Benefit-andBreakdown-for-ASP.pdf

[3] Cho, K. M. (2002, May). Training needs of agricultural extension agents in Myanmar. Paper presented at the 18th Annual Conference of Association for International Agricultural and Extension Education (AIAEE), Durban, South Africa (pp. 72-80).https://www.aiaee.org/attachments/article/1322/cho72-80.pdf

[4] Denning, G., K. Baroang and T.M. Sandar. (2013). Rice Productivity Improvement in Myanmar. United State Agency International Development. Food Security Group, Michigan State University.

[5] Extension Division, Department of Agriculture. (2012. 2013. 2014). Annual Report. Ministry of Agriculture, 
Livestock and Irrigation, Nay Pyi Taw, Myanmar.

[6] Gautam, M. (2000). Agricultural extension: The Kenya experience: An impact evaluation. World Bank Publications.

[7] Horstkotte-Wesseler, G., M. Maredia, D. Byerlee and G. Alex (2000). Ex Ante economic analysis in AKIS projects: Methods and guidelines for good practice. Retrieved from http://agris.fao.org/agris-search/search. do?recordID $=$ US2014605060

[8] Hussain, S. S., D. Byerlee and P. W. Heisey. (1994). Impacts of the training and visit extension system on farmers' knowledge and adoption of technology: Evidence from Pakistan. Agricultural Economics, 10(1), 39-47. http:// www.sciencedirect.com/science/article/pii/0169515094900388

[9] Luukkainen, J. (2012). A Comparison of Extension Methods Used by Different Agricultural Extension Service Providers in Nyandarua County, Kenya. Retrieved from http://www.theseus.fi/handle/10024/49890

[10] Morris, M. L, R. B. Tripp and A. A. Dankyi. (1999). Adoption and impacts of improved maize production technology: A case study of the Ghana Grains Development Project.

[11] Nigussie, T and D. Mulat. (2003). The productivity and profitability of wheat and teff technologies: comparison between extension and non-extension plots in three selected villages of Ethiopia. In Proceedings of the National Workshop on Technological Progress in Ethiopian Agriculture, Addis Ababa, Ethiopia.

[12] Oakley, P and C. Garforth. (1985). Guide to extension training (No. 11). Food and Agriculture Organization of the United Nations. FAO.

[13] Ponniah, A., R. Puskur, S. Workneh and D. Hoekstra. (2008). Concepts and practices in agricultural extension in developing countries: A source book. International Food Policy Research Institute (IFPRI) and Nairobi: International Livestock Research Institute (ILRI). Washington, DC: Publishinng.

[14] Rice Division, Department of Agriculture, (2015). Annual Report. Ministry of Agriculture, Livestock and Irrigation, Nay Pyi Taw, Myanmar.

[15] Wale, E and A. Yalew. (2007). Farmers' variety attribute preferences: implications for breeding priority setting and agricultural extension policy in Ethiopia. African Development Review, 19(2), 379-396. http://onlinelibrary.wiley. com/doi/10.1111/j.1467-8268.2007.00167.x/full

[16] Win, N. K. (2015). 2014/2015 Report on hybrid rice seed production in Myanmar. Ministry of Agriculture, Livestock and Irrigation, Nay Pyi Taw, Myanmar. 